\title{
Costs and Procurement for Cross-Laminated Timber in Mid-Rise Buildings
}

\section{Anne Gunnarshaug Lien*, Nicola Lolli}

SINTEF Building and Infrastructure, Norway

*Corresponding author: Anne.G.Lien@sintef.no

$\Gamma$ Grossef http://dx.doi.org/10.5755/j01.sace.25.2.22099

The objective of this paper is to report on and analyse strategies for cost reduction, design processes and procurement models of a wooden nearly zero energy building (nZEB) in Norway. This publication is part of the dissemination activities of the EU Horizon 2020 project NERO, whose scope is to demonstrate the feasibility of cost reduction of nZEBs built in wood in the Nordic countries. Case buildings from Estonia, Finland, Norway and Sweden are studied with respect to their technological solutions, energy use and construction cost. The Norwegian building investigated in this paper is the Moholt Allmenning, a newly built student accommodation located in Moholt, Trondheim. Interviews with the building's owner and the contractor were carried out to obtain information on the decision-making process during the procurement phase, the planning phase and the execution phase. The results show that the environmental goal and the requirement for the use of wood set out in the tender announcement were decisive driving forces for the selection of cross-laminated timber (CLT) in the final design. The results also show that the cost of using CLT in student residences is competitive when compared to using concrete and steel. Given the requirement for minimal greenhouse gas (GHG) emissions from materials production in nZEBs, the use of CLT is, however, a better choice.

Keywords: CLT, cross-laminated timber, nZEB, procurement, GHG emissions, Architecture competition

The Moholt Allmenning was commissioned by Sit (Studentsamskipnaden i Gjøvik, Ålesund and Trondheim) in 2013 through a design competition named Moholt 50/50. Sit is a student welfare organisation that plan, build and run student accommodations. The Moholt Allmenning (Moholt 50-50 Trondheim) is an extension of the old Moholt student residence complex in Trondheim, see Fig. 1. The new construction consists of five nine-storey towers. Each floor typically accommodates 15 residential units, with a total of 632 units. Located on the five ground levels are a healthcare centre, fitness centre, hairdresser, shared laundry and an international food shop. The new complex also hosts a kindergarten for 171 children as well as an activity centre with public library. The student rooms include private bathrooms and are organised in a Y-shaped layout around the common area/kitchen/dining area. The towers are built with cross-laminated timber (CLT) as load-bearing systems. Inside, the wood surfaces are exposed and are clearly visible in the student apartments. The building's energy efficiency solutions were designed to comply with the Norwegian passive house standard (NS 3700, 2013).

\section{Introduction}

Costs and Procurement for Cross-Laminated Timber in Mid-Rise Buildings

Received 2018/12/11

Accepted after revision 2019/02/25

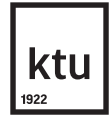

Journal of Sustainable Architecture and Civil Engineering Vol. 2 / No. 25 / 2019 pp. 43-52 DOI 10.5755/j01.sace.25.2.22099 


\section{Wooden nearly zero energy buildings (nZEBs) in Norway}

Norway is yet to specify nearly zero energy buildings (nZEBs) (Directive 2010/31/EU, 2010) as a target for the energy performance of Norwegian buildings. The most ambitious energy performance target for buildings, available in the Norwegian regulations so far, is the Norwegian passive house standard (NS 3700, 2013). This standard specified a slightly more ambitious building energy performance target than that of the currently enforced Norwegian building code (TEK17). Other benchmarks that define building energy performance and environmental goals are available, such as BREEAM-NOR and Zero Emission Building (ZEB). The latter specifically targets the buildings' lifecycle greenhouse gas (GHG) emissions due to the energy use from the production of the building materials up to and including the buildings' demolition. Given the lack of a Norwegian definition of nZEBs, the labelling (in terms of energy) of the Moholt Allmenning is therefore compared to the requirements set in TEK17. The energy meter from one of the residential towers of the Moholt Allmenning shows that the building used $80 \mathrm{kWh} / \mathrm{m}^{2}$ in 2017 . This includes electricity for heating, domestic hot water, lighting, appliances, ventilation and water pumps. Since the Moholt Allmenning uses less energy than the limits defined in TEK 17 (which is set to $95 \mathrm{kWh} / \mathrm{m}^{2} \mathrm{y}$ for residential buildings), the building is placed in energy class $A$, according to the Norwegian energy classification (Energimerking).

The use of wood in building construction has a significant potential for reducing GHG emissions (Skullestad et al. 2016, Skaar et al. 2017, Malmqvist et al. 2018, Østnor et al. 2018).

Moreover, the benefits of urban densification in terms of reduced lifecycle GHG emissions for transport and building construction is undoubted (Bergesen et al. 2017, Göswein et al. 2017, Fercovic and Gulati 2016). In this respect, the current Norwegian building industry is investigating the opportunities for combining the goals of urban densification with the use of wood in building construction. The recent construction of a mixed-used tower (residential, hotel, swimming pool, offices, restaurants) that is 80 metres high with 18 floors in Mjøsa - being erected with CLT and glulam elements - sets a new benchmark for the use of engineered wood in building construction (Mjøstårnet, Moelven). The shift from concrete to wood in the Norwegian building industry requires a tremendous effort in order to be realised. Currently, the concrete industry is responsible for the majority of large constructions being erected in Norway as a result of installing concrete floors in $70 \%$ and $45 \%$ of non-residential buildings and apartment buildings, respectively (Betongelement Foreningen 2017). Wooden elements are mostly used for frames of small buildings (such as single-family houses and cabins), frames of non-load-bearing facades and for cladding (Treindustrien.no). The use of wood in large buildings also requires additional safety and attention with respect to fire safety and noise propagation; this is likely to introduce additional cost to the building process in order to satisfy the current building requirements (Structural Timber Association 2014, Buchanan et al. 2014, Hoeller et at. 2017, Pagnoncelli and Morales 2016).

The aim of this work is to give an insight into the decision-making process before and during the construction of the Moholt Allmenning. Special focus is given to the procurement route and the cost reduction strategies used in the process. This work is part of the Horizon 2020 NERO project, which "develops and demonstrates nearly zero energy wood buildings design processes and procurement models with reduced cost for large-scale use in the northern climatic conditions and on performance level of near zero and beyond" (NERO Wood for Zero). The objective of the NERO project implies that the choice of design process and procurement model influences the final cost of a wooden nZEB building. The work presented in this paper aims at finding what type of relationship exists between the design process, the procurement model and the final cost of the building.

Structured interviews were carried out with the stakeholders of the Moholt Allmenning during the autumn of 2018. At that time, the buildings had been occupied for two years. Three interviews were carried out: two with the building owner, Sit, and one with the contractor. From Sit, the head of project development (1) and the project leader for Moholt Allmenning (2) were interviewed. The 
project leader holds their role for four years, spanning the procurement process, the planning process and the erection of the buildings. From the contractor, the project leader was interviewed (3). In addition, a site tour was given and led by the building manager. Documents from the competition period were analysed. These comprised the competition programme and the invitation to prequalification, which was issued to "wildcard" architects as part of the Norwegian Wildcard Programme to encourage the growth of newly established architecture firms (Wildcard, 2011). The interviews were based on a guideline developed in the NERO project. The mapping of the procurement route shown in Fig. 3 was, in the end, discussed with the project leader from Sit and adjusted.

The aim of the interviews was to answer the following main question: "What is the relationship between the objectives of the project, the use of CLT, the procurement process, costs and the degree of innovation?" The questions asked to the interviewees were structured under four themes (procurement process, use of CLT, innovation and cost) and they were:

- Introduction

_ What role did you have in the project? (owner, buyer, project developer, architect, contractor)

- What functional and technical requirements were defined for the building?

- Does your company have a strategy document for environmental goals in procurement and implementation?

- The procurement process and implementation model

_ Can you describe the procurement route?

_ What was the criteria for the tender competition?

_- Which contractual form was chosen?

_ Was there a kind of cooperation?

- Use of CLT

_ Why was CLT chosen?

_. Did the parties have experience with the use of CLT?

_ Will you use CLT in future projects?

Innovation

_ What was the level of innovation in the project?

Cost

_- What was the cost in relation to the budget?

-What was the connection between procurement, contracts and costs?

_ What are the expectations of the future impact on costs of an increased market share for CLT?

_ Do trust, enthusiasm and coherent goals have a bearing on the quality and cost of the building?

The main phases of the building process followed the timeframe below:

2012-2013: Planning and design phase with architecture competition in the spring of 2013.

Results

2013-2015: Procurement and cooperation phase.

2015-2016: Construction phase.

The procurement route and the design phase step by step:

1. Sit (the building owner) defined the limit and goals for energy use, $\mathrm{CO}_{2}$ emissions and cost of the building.

2. An open prequalification competition (with negotiation) for wildcard architects was announced and four architect firms were chosen. 
3. Sit arranged a workshop for the wildcard firms and 50 other attendants to get input to the architecture competition.

4. An architecture competition for the four firms was carried out. The winner was MDH Architects, together with Arne Henriksen Architects as the coaching firm and MASU Planning (from Copenhagen) as landscape architects. The winning design was proposed with a steel and concrete structure and brick as cladding to integrate the new design with the existing buildings.

5. Sit was then contacted by Trebruk and iTRE, who encouraged the use of CLT in the design instead of the proposed steel and concrete structure because of the lower GHG emissions of wood and its competitive cost.

6. A project team consisting of Sit, $\mathrm{MDH}$ Architects and consultants engaged by Sit developed the pre-project for the tender announcement with a goal for $50 \% \mathrm{CO}_{2}$ reduction compared to a steel and concrete building in accordance with the Norwegian building code of 2010. The energy performance should meet the passive house standard.

7. A prequalification phase was initiated, and four contractors were chosen.

8. The four contractors, with their consultants, MDH Architects, and professionals from Sit were trained by Trebruk and iTRE on how to build with CLT. They also visited CLT projects in Norway.

9. The contractor, Veidekke AS, won the competition for the prime contract with cooperation.

10. Sit, MDH Architects and Veidekke, with their consultants, developed the project in cooperation to be a cost-effective project.

11. The board of Sit approved the comprehensive contract with Veidekke, and the building process could start.

12. The system for involving planning in engineering (IPP) was followed, during both the cooperation phase and the detailed design phase.

13. Involving planning (IP) was carried out throughout the construction phase and the "Porsche system" of construction (described later in the paper).

14. Due to the use of CLT instead of cast-in-place concrete, the construction phase was shortened by four months.

\section{Environmental goals and architecture competition}

The goals for energy use, $\mathrm{CO}_{2}$ emissions and construction cost were defined from the start. Student apartments in Norway should be built within a certain cost limit to achieve public grants from the Norwegian public authorities. The owner (Sit) had previous experience of the difficulties in keeping the total cost of the student housing below the initially defined limit, so the criteria for the tender announcement were therefore set to obtain the best building quality within the required cost limit.

Sit strategy aims for architectural qualities and environmental goals for student accommodation projects, including universal design, being good examples of high energy efficiency buildings (meeting passive house standard or higher energy performance), use of renewable energy and reduction of GHG emissions. Sit therefore defined a template for the procurement process and construction process with defined demands for environmental goals.

Architecture competitions have often been used by Sit because they are the best opportunity to obtain a high-quality architecture that provides a good environment for the students. Specifically, for the Moholt 50/50, an important goal was to achieve an innovative design with the best solutions for blending the new design in to the existing student residence complex. Sit was encouraged to go for a wildcard competition. Wildcard is a Norwegian register for young architect firms founded in 2011. For the competition, the wildcard firm could bring along an experienced firm as a "coach- 
ing firm". An open prequalification competition was announced for firms in the Norwegian Wildcard Register. Criteria for the prequalification was based on understanding of the task, description of the team and how the team is put together, and relevant reference projects.

Four firms were chosen. They participated in a workshop together with Sit, the municipality of Trondheim, residents from the Moholt student complex, neighbours, representatives from the universities and the Norwegian State Housing Bank. The intention was for the participants to understand the user's needs and to receive and give input for defining the criteria of the architecture competition before its official announcement. During this workshop, Sit got to know the four architect firms and the firms became acquainted with Sit's vision and goals for the Moholt 50/50. Criteria for selecting the winning project were the architectural quality, social and environmental values and the capability to implement the proposed design.

The four entries to the competition turned out to be very different and represented a wide range of solutions for the Moholt area. This gave Sit an overview of the feasibilities for the area and helped them to understand the best design strategy. The four entries were presented to a jury and to a
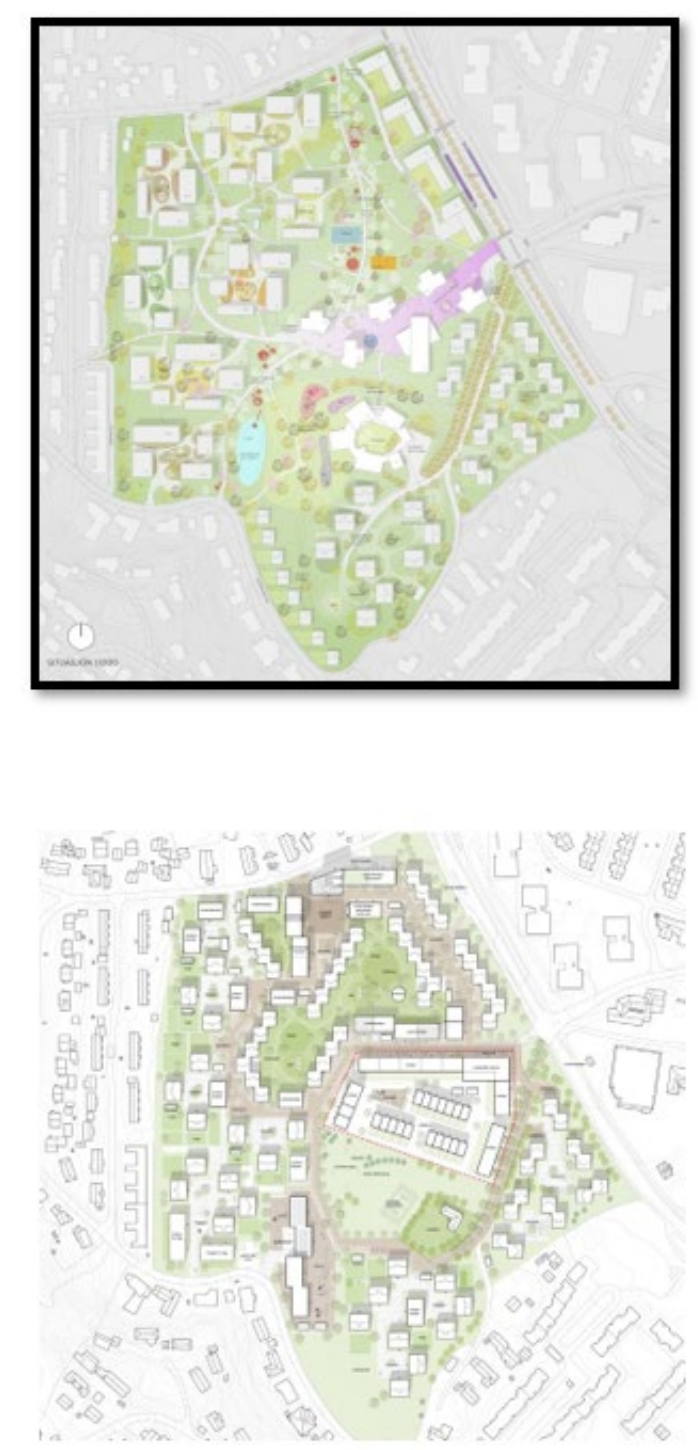
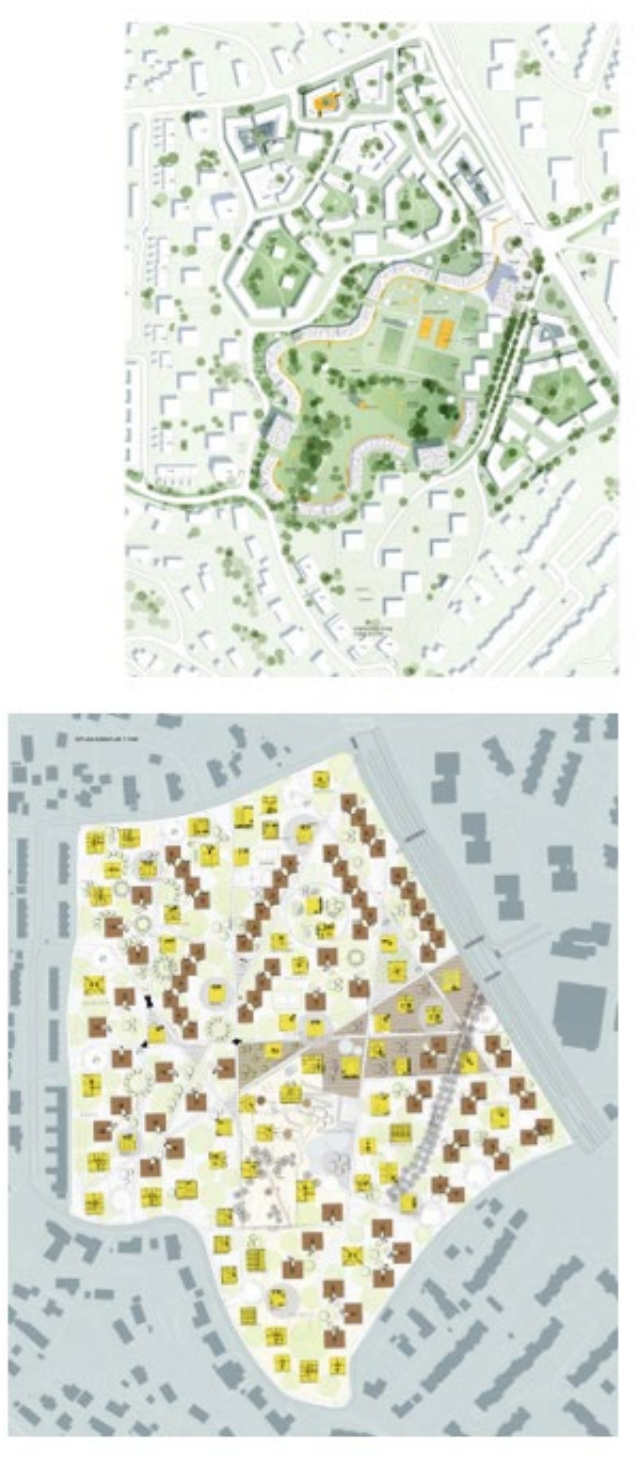

Fig. 2

Site plans of the four competing entries (Source: Jury report 2013), The winning entry (upper-right) concentrated the building volume around the common area, the "Allmenning". The other entries had different levels of dispersed infill of the area 
committee from Sit. The jury gave a report and suggested a winner. The Sit committee evaluated the entries, the presentations from the competitors and the report from the jury and gave their recommendation to the Sit board for decision.

The winning team was MDH Architects, with Arne Henriksen Architects as the coaching firm and MASU Planning (from Copenhagen) as landscape architects. The winning entry had steel and concrete as the load-bearing system and brick as cladding - in line with the existing part of the student residence area.

The criteria for the architecture competition had no requirements regarding the use of specific structural systems for the design. The decision to use CLT came at the end of the design competition, on suggestion from Trebruk AS as a "wood promoter" and iTRE as a CLT adviser. This was in line with Sit's strategy for low GHG emissions. The board then agreed on assessing CLT constructions for Moholt 50/50. The board of Sit visited CLT producers and CLT buildings in Austria and CLT buildings in Norway, and listened to experts and experience from other builders. The board was, in the end, convinced that CLT construction would be good for the users, good for the environment and that the costs would not be higher than construction in steel and concrete.

\section{Tender announcement and contracts}

Sit is not a public organisation, but is based on an "Act of Law" from 1948. Rules for public procurement are to be followed only when public grants cover more than $50 \%$ of the total cost of a building project. For Moholt 50/50, only $37 \%$ of the cost was covered by public grants. Irrespective, the board of Sit always recommend arranging a tender competition.

Four contractors were invited for prequalification for an invited tender announcement. The four contractors had little or no experience in building with CLT. To prepare and motivate the contractors for the bid with CLT, Sit arranged a special course for them together with the architects, the consultants, the "wood promoters" and the CLT producers. They also visited Norwegian CLT projects together.

The pre-project, with its goals of CLT usage and environment and quality performance, was then developed by Sit, MDH Architects and the consultants engaged by Sit to define the tender competition. The contract form which was used was the "prime contract with cooperation", during the planning phase and "prime contract" for the construction phase. The criteria for the tender competition were:

$50 \%$ of crediting points were given to the final price (total tender cost, proportion for additional payment (mark-up payment), and cost per hour); and

$50 \%$ of crediting points were given to the contractor's qualifications and ability to cooperate (CV and references for key personnel, the implementation/execution model during the design and construction phase, references for buildings meeting passive house standard and the use of CLT, and a system for follow-up during the guarantee period).

The contractor Veidekke won the competition. The cooperation phase lasted for about four months. During this time, the IPP method (involving planning and design) was used. During the cooperation period, cost-effective and smart solutions were developed. This resulted in an extension to the size of the projects from providing for 465 students up to 632 students. The towers were extended from eight to nine storeys. All parts of the design team worked together to develop the solutions that were the basis for the prime contract for the construction. Sit, the architects, the consultants, the contractor and some of the material suppliers were involved. The foundation for the cost-effective solutions chosen were the cooperation between the building owner, the architect, the consulting engineers and the contractor. 


\section{The construction phase}

One of the criteria for the tender competition was the process to be used for implementing the design in the construction phase. The winning contractor uses the "Porsche system", which is used for planning and implementation based on processes in the car industry. According to the "Porsche system", the implementation plan is followed weekly and the time allocated to each activity is adjusted to match the plan. This ensures that all the activities at the building site follow the same plan. The construction time was 20 months and the involved parties (suppliers, the contractor, consultants, and so on) planned the construction phase together during the previous cooperation phase to optimise the work schedule.

Mid-rise buildings of more than four storeys built with CLT are quite a novelty in Norway because Norwegian contractors have very little experience with the use of CLT. The contractor Veidekke defined a company strategy that follows national goals for the reduction of GHG emissions. About $75 \%$ of all dwellings in Norway are wooden detached houses or other kinds of small wood houses, but the current trend shows that building density in Norwegian cities is increasing, with more mid-rise apartment buildings and fewer detached houses being built. This may result in a shift away from small wooden dwellings towards concrete apartment buildings. A more GHG-friendly development for the future might, however, be a development that moves towards apartment buildings with CLT constructions.

The advantages of building with CLT, according to the interviewed stakeholders of the Moholt 50/50 competition, are:

_ The embodied GHG emissions from the material are lower;

- A good indoor climate is provided;

_ The low density of the structural frame simplifies the foundation design;

- The construction time is faster with CLT than with concrete;

- The working conditions on site are improved, with less dust, noise and better temperatures; and

- Total costs, including the financial costs, are competitive compared with other solutions.

The disadvantages are:

- The cost for CLT elements is high;

_ There is a lack of experience and knowledge among architects, consultants and contractors; and

There is a lack of pre-accepted solutions for fire and noise protection.

The experience from the Moholt project shows that innovative solutions are developed both during the early design phase and during the cooperation phase before the contracting phase. CLT was used for load-bearing constructions and for floors above the second floor. Wood surfaces are exposed in the ceilings and in at least one wall in each student apartment. The corridors and the kitchen have exposed wood in the ceilings and the walls. The roof, stairs and lift shaft are also made of CLT. The owner stated that the façade solution is the most innovative solution of the project; to avoid damage due to shrinkage of the wood construction, a "telescope façade of wood" was developed. The façade cladding is built like pine shells, overlapping each other.

\section{Costs}

Moholt 50/50 got financial grants from the public enterprise Enova for building to meet the passive house standard, which requires better energy performance than the national building code. They also received grants from the public enterprise Innovation Norway for the development of the CLT concept, for educating contractors and for fire safety testing. Sit is satisfied with the experience of building Moholt and is optimistic about the costs. The project leader at Sit believes that 
the cost for CLT buildings will be more competitive than concrete buildings once all actors in the building market have gained enough experience and knowledge.

According to the project leader at the contractor Veidekke, the cost for building with CLT compared to steel and concrete varies greatly for different building types. Apartment buildings, kindergartens and other buildings with relatively small rooms are easy to build with CLT, while office buildings - with the need for large open areas and flexibility - are more challenging. CLT elements are more expensive than concrete elements, but the financial costs are lower due to the shorter erection time for the building. The total cost for Moholt 50/50 and for new CLT apartment buildings are, therefore, promising. The contractor also stated that all parts in the project must invest resources to be winners in a new market. The contractor, however, has more focus on the environmental issues than on the costs and believes that demand for solutions with reduced GHG emissions will be a growth market.

\section{Developing the project and building the design team}

The list above for the procurement route and design phase is, at first sight, long and complex. The complexity is due to the owner, Sit, taking an active part in developing the project and in building a knowledgeable design team. A large part of the definition work is done in the early planning phase in cooperation between the owner, the architect, the contractor and the consultants. In Fig. 3, the key stages of the procurement route are mapped to show the connections between all actions. Trust between all parties is vital for a positive end result. The contractor stated that Sit made a good foundation for trust throughout the whole process of planning and construction. When they gave the information about building with CLT to the four competing prequalified contractors before the tender competition, a mutual understanding was established between the purchaser and the bidders. A common understanding is that the procurement process can be used to secure both the good team work in all stages, and a high-quality end product.

Fig. 3

Mapping the procurement route, development of the project and building up of the design team

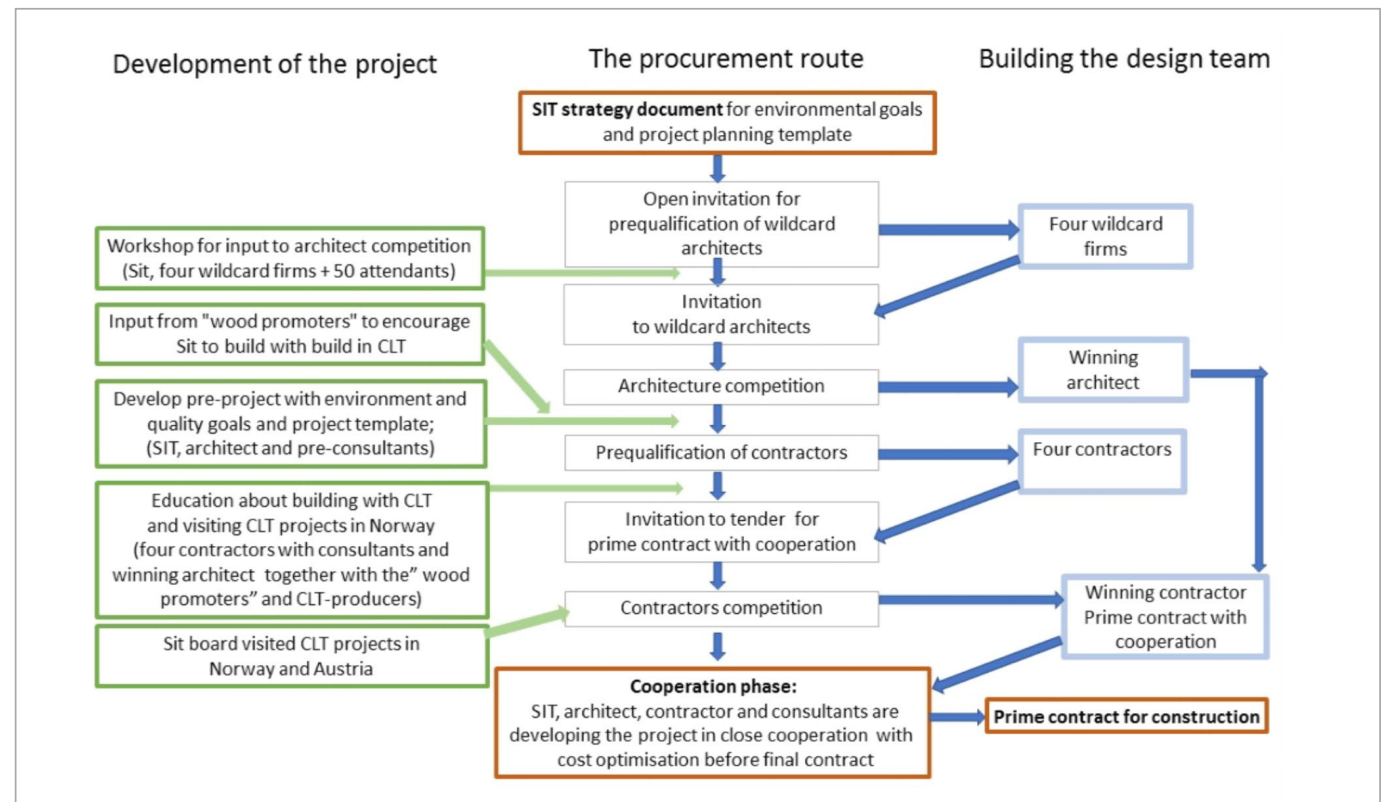

The work presented in this paper aims to discover the type of relationship that exists between the design process, the procurement model and the final cost of CLT buildings.

The results show that the purchaser's knowledge and experience, the environmental goal and the request for the use of wood in the tender announcement were decisive driving forces for 
using CLT for Moholt Allmenning. The results also show that the construction costs of CLT buildings are competitive when compared to similar buildings built in concrete and steel. For nZEBs, which are subject to restrictions on GHG emissions from materials production, the use of CLT is, however, a better choice than the use of steel and concrete.

It is crucial that the project owners have good knowledge of the qualities they want to achieve, and knowledge about how to ask for these qualities in the bid announcement. Poor specification will give the contractors the opportunity to win the competition on low price but with a low-quality end product. Good specification is therefore crucial for obtaining the desired qualities for the building.

It is not easy to predict how costs may develop for CLT buildings once more experience is achieved. More experience will, however, always result in increased efficiency. A growing

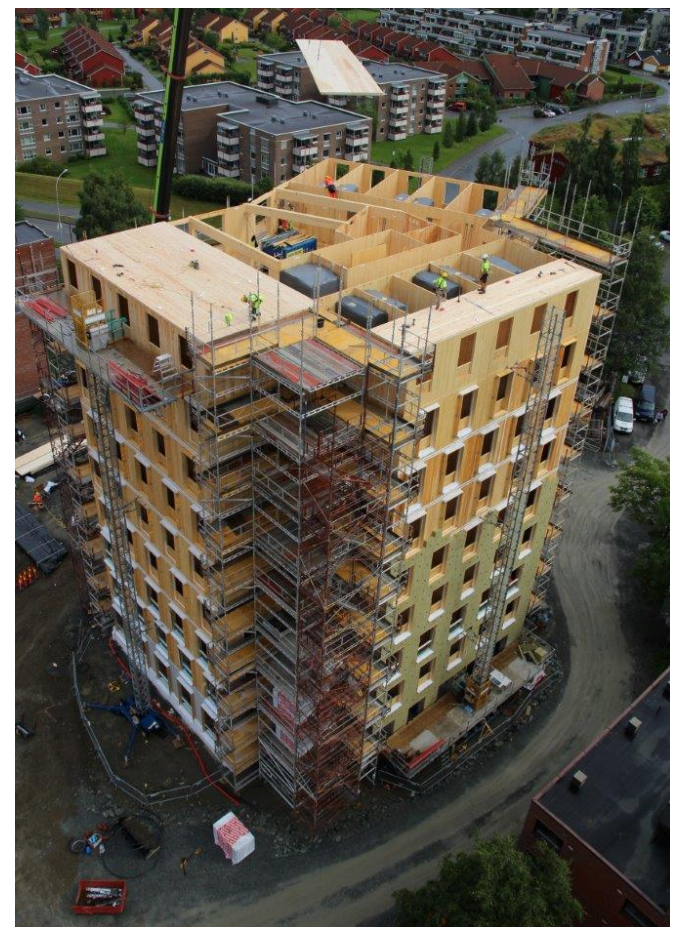
demand for low-GHG solutions will most likely result in a demand from public building developers for CLT buildings. This is what the market needs to achieve the experience necessary to develop competitive, cost-effective solutions.

\section{Acknowledgement}

This work was financed thanks to the contribution of the EU Horizon 2020 NERO - Nearly Zero Energy Wooden Buildings in Nordic Countries, grant agreement 754177.

Bergesen J.D., Suh S., Baynes T.M., Musango J.K., Environmental and natural resource implications of sustainable urban infrastructure systems, Environmental Research Letters, 12 (12) (2017). https://doi. org/10.1088/1748-9326/aa98ca

Betongelement Foreningen, Årsmelding 2017 (Concrete elements 'society, year book 2017)

Buchanan A., Östman B., Frangi A., Fire Resistance of Timber Structures, National Institute of Standards and Technology, 2014. https://doi.org/10.6028/ NIST.GCR.15-985

Directive 2010/31/EU of the European Parliament and of the council of 19 May 2010 on the energy performance og buildings (recast).

Fercovic J., Gulati S., Comparing household greenhouse gas emissions across Canadian cities, Regional Science and Urban Economics, 60 (2016) 96-111. https://doi.org/10.1016/j.regsciurbeco.2016.06.010

Göswein V., Krones J., Celentano G., Fernández J.E., Habert G., Embodied GHGs in a Fast-Growing City:
Looking at the Evolution of a Dwelling Stock using Structural Element Breakdown and Policy Scenarios, Journal of Industrial Ecology, 22 (6) (2018) 1339-1351. https://doi.org/10.1111/jiec. 12700

Hoeller C., Mahn J., Quirt D., Schoenwald S., Zeitler B., Apparent sound insulation in cross-laminated timber buildings, in: NRC Publications Archive, National Research Council Canada, 2017. https://doi. org/10.1121/1.4987243

Malmqvist T., Erlandson M., Francart N., Kellner J., Minskad klimatpåverkan frpn flerbostadshus, Stockholm 2018

Norsk Standard (2013) NS 3700:2013, Kriterier for passivhus og lavenergibygninger - boligbygninger. Oslo: Standard Norge.

Pagnoncelli L., Morales F., Cross-laminated timber system (CLT): laboratory and in situ measurements of airborne and impact sound insulation, EuroRegio 2016, Porto, Portugal, European Acoustic Association.
Fig. 4

Erection of a tower at Moholt Allmenning. The wood elements and prefabricated bathrooms are added floor by floor. Photo: Sit

\section{References}


Skaar C., Solem B., Rüther P., Composite floors in urban buildings: Options for a low carbon building design, 6th Forum Wood Building Nordic Trondheim 17, Trondheim Norway, 2017.

Skullestad J.L., Bohne R.A., Lohne J., High-rise Timber Buildings as a Climate Change Mitigation Measure - A Comparative LCA of Structural System Alternatives, Energy Procedia, 96 (2016) 112-123. https://doi.org/10.1016/j.egypro.2016.09.112

Structural Timber Association, Fire safety in timber buildings, in: Structural Timber Engineering Bulletin 7, 2014.

Østnor T., Faanes S., Lædre O., Laminated timber versus on-site cast concrete: a comparative study, in: Proc. 26th Annual Conference of the International Group for Lean Construction (IGLC), González, V.A. (ed.), Chennai, India, (2018) 1302-1312. https://doi. org/10.24928/2018/0313
Directive 2010/31/EU: https://eur-lex.europa.eu/legal-content/EN/TXT/?uri=CELEX\%3A32010L0031, last accessed 07/02/19.

TEK17: Www.dibk.no/byggereglene/byggteknisk-forskrift-tek17/, last accessed in 2019.

Moholt 50-50 Trondheim: www.arkitektur.no/moholt-5050, last accessed in 2018.

Energimerking: www.energimerking.no/no, last accessed in 2018.

Treindusrtien: www.treindustrien.no, last accessed in 2018.

NERO Wood for Zero: www.neroproject.net, last accessed in 2018.

Mjøstårnet, Moelven: www.moelven.com/mjostarnet, last accessed in 2018.

Wildcard: www.arkitektur.no/om-wildcardordningen, last accessed in 2019.

\section{About the Authors}

\section{ANNE GUNNARSHAUG LIEN}

Senior research scientist

SINTEF Building and Infrastructure

\section{Main research area}

Energy efficiency in buildings and architecture

\section{Address}

Høgskoleringen 7b, 7465 Trondheim, Norway E-mail: Anne.G.Lien@sintef.no

\section{NICOLA LOLLI}

Research scientist

SINTEF Building and Infrastructure

\section{Main research area}

Energy efficiency in buildings

\section{Address}

Høgskoleringen 7b, 7465 Trondheim, Norway

E-mail: Nicola.lolli@sinte 